\title{
SARS-CoV-2 and the Pollution Exposure of the Population Near to an Industrial area on the Metropolitan Region in São Paulo State, Brazil
}

\section{Maria Angela Zaccarelli-Marino}

Faculdade de Medicina do ABC

Thalles Zaccarelli Balderi

Santa Paula Hospital: Hospital Santa Paula

Felipe Mingorance Crepaldi

$A B C$ medical school

\section{Rudá Alessi}

ABC medical School

Marco Martins ( $\nabla$ mmartins@hsph.harvard.edu )

Harvard University HSPH: Harvard University T H Chan School of Public Health https://orcid.org/00000002-0771-9697

\section{Research}

Keywords: SARS-CoV-2, atmospheric pollution, inflammation, autoimmune, Brazil

Posted Date: December 3rd, 2020

DOl: https://doi.org/10.21203/rs.3.rs-117250/v1

License: (1) This work is licensed under a Creative Commons Attribution 4.0 International License. Read Full License

Version of Record: A version of this preprint was published at Fortune Journal of Health Sciences on January 1st, 2022. See the published version at https://doi.org/10.26502/fjhs.046. 


\section{Abstract}

Background: The epidemic caused by severe acute respiratory syndrome coronavirus 2 (SARS-CoV-2) yielded intense respiratory illness clusters and has progressed rapidly into a pandemic. Objective: Evaluating the pre-existing conditions (rhinitis, sinusitis, pharyngitis, obstructive pulmonary diseases (OPD), conjunctivitis, dermatitis, and primary hypothyroidism $(\mathrm{PH})$ ) in residents exposed to long-term air pollutants and their higher risk of complications in case of infection with SARS-CoV-2.

Methods: 2004 residents of both sexes, aged 8-72 years old, had responded to a home-based questionnaire. SARS-CoV-2 cases were collected from the Greater ABC Region, an industrial region of the São Paulo State, Brazil, part of the São Paulo Metropolitan Region. With a focus on the Capuava Petrochemical Complex influence area, using the combination of the AERMOD dispersion model with the Weather Research Forecast (WRF) meteorological model (2016), we evaluated the Greater ABC region. Atmospheric pollutant concentrations were analyzed in 2017 using meteorological data from 2005 to 2009, correlating this data with the research done from 2003 to 2005.

Results: nitrogen dioxide (NO2), carbon monoxide (CO), particulate matter (PM10), sulfur dioxide (SO2), and Volatile organic compounds (VOCs) concentrations presented the highest correlations between the rhinitis, sinusitis, pharyngitis, OPD, conjunctivitis, dermatitis and $\mathrm{PH}$ odds and pollutant concentrations.

Conclusion: We demonstrated that the closer the individuals live from the Petrochemical complex, the higher their risk of death from SARS-CoV-2. Given the asymptomatic characteristic of the disease in its initial development individuals and the risk of its complications, we suggest that the employees of chemical plants and residents living around industrial areas must be continuously evaluated for SARSCoV-2.

\section{Introduction}

Metropolitan regions are important for public health because of the large number of people living in them, and the air pollution levels usually are higher than in other areas. The industrial installation close to residential areas, together with unfavorable topography conditions to the dispersion of pollutants, could cause health risks (Ribeiro and Assunção 2001).

The health of residing living near petrochemical industrial complexes is a critical concern due to potential pollution emissions. Industrial plants can increase the concentration of hazardous substances in surrounding areas and cause respiratory symptoms among residents (Zhang et al. 2010).

A study realized in Spain used the International Study on Asthma and Allergies in Children's questionnaire to survey the population. They observed a higher prevalence of nocturnal cough among children (aged 67 years) and adolescents (aged 13-14 years), who lived within a petrochemical industrial complex in Tarragona when compared with those living in areas of the country without a Petrochemical Complex (Rovira et al. 2014). 
Since the Coronavirus disease (COVID-19) emerged in Wuhan, China, in December 2019 (Li et al. 2020), the epidemic caused by severe acute respiratory syndrome coronavirus 2 (SARS-CoV-2), caused clusters of severe respiratory illness (Huang et al. 2020) has progressed rapidly into a pandemic.

A rapid and robust response by the global scientific community has described many essential aspects of SARS-CoV-2 transmission and natural history (Bi et al. 2020; Chen et al. 2020; Lauer et al. 2020; Backer et al. 2020; Chan et al. 2020), but critical questions remain (Bi et al. 2020).

The World Health Organization (WHO) has defined this new syndrome with the acronym COVID-19 for Corona Virus Disease 2019 (WHO 2020). At the beginning of April 2020, it appeared that there were remarkable differences in the spread rate and mortality of the outbreaks by COVID-19 in different countries of the world. Early studies concluded that the risk factors associated with the development of the disease are older age (Wu et al. 2020), history of smoking (Liu et al. 2020), and heart disease (Shi et al. 2020).

After that, the number of infected people increased rapidly, and, a month later, the outbreak turned into a national crisis, with infected individuals diagnosed all over the country (Chan et al. 2020).

As of June 16, 2020, there were 7,941,791 confirmed cases of COVID-19 and 434,796 deaths worldwide, and 867,624 confirmed cases of COVID 19 and 43,332 deaths in Brazil (World Health Organization Coronavirus Disease (COVID-19) 2020; Johns Hopkins 2020).

COVID-19 has been associated with a high rate of infection and lethality, especially in patients with comorbidities (Kakodkar et al. 2020), and is characterized by fever, cough, fatigue, shortness of breath, pneumonia, and other respiratory tract symptoms (Chen et al. 2020; Wang et al. 2020) and in many cases, progresses to death.

The chronic obstructive pulmonary diseases (COPD) are among the leading causes of morbidity and mortality in high - and low- income countries and a significant public health burden worldwide (Liu et al. 2016). In the United States, COPD affects over $6.5 \%$ of adults, is the third leading cause of death, and incurs 700,000 inpatient stays, 1.5 million emergency room visits, and USD 32 billion in cost annually (Ford et al. 2015).

In the 1960s, the prevalence of asthma and allergic diseases began to increase worldwide. Currently, the disease's burden is more than 300 million people affected (Litonjua and Weiss 2007).

The association between air pollution and respiratory infections has been a public health concern in recent years (Su et al. 2019); however, both public and scientific interest was heightened since the outbreak of the coronavirus disease 2019 (COVID-19) pandemic (Lewis 2020).

Petroleum processing can emit different organic compounds that can threaten human health (Godoi et al., 2013). The operations of the petrochemical industrial complex (PIC) generate various air pollutants, such as volatile organic compounds (VOC), sulfur dioxide (SO2), particulate matter (PM), and nitrogen 
oxides (NOx) (Rodríguez et al. 2004; Wichmann et al. 2009; Tanyanont and Vichit-Vadakan 2012; Hsu et al. 2018; Omidvarborna et al. 2018).

VOCs are organic compounds with one or more carbon atoms with very high vapor and pressure, making them readily evaporate into the atmosphere at room temperature. Some examples include acetone, benzene, ethylene glycol, formaldehyde, methylene chloride, perchloroethylene, toluene, xylene, 1, 3butadiene (Minnesota Department of Health 2010).

High NO2 concentration is significantly associated with respiratory mortality (Chen et al. 2007; Hoek et al. 2013) and is also responsible for generating some harmful secondary pollutants such as nitric acid (HNO3) and ozone (03) (Khoder 2002).

The question of whether the COVID-19 can be spread by airborne has been asked both in the scientific community and the general public since the virus arrival. Like fine particulate matter (PM2.5), viruses are among the inhalable biological particles that may be airborne. Recent studies have shown that viruses become airborne through sneezing, coughing, and maybe dispersed further as they commingle with PM2.5 (Frontera et al. 2020).

Coarse Particulate Matter (PM10-2.5) is aerodynamic inhalable particles between $10 \mu \mathrm{m}$ and $2.5 \mu \mathrm{m}$. They are generally found near roadways and dusty industries. They are considered to be of regulatory interest because they may penetrate up to the level of lower respiratory tracts and the gas exchange portion of the lung (Frontera et al. 2020).

There are few epidemiologic studies related to air pollution, chemical industries and rhinitis, sinusitis, pharyngitis, and obstructive pulmonary diseases (OPD) as asthma and COPD. The studies in South America have identified associations between residential proximity to a petrochemical plant and asthma, rhinitis, cough, and wheezing (Wichmann et al. 2009; Moraes et al. 2010).

Previous studies have found that air pollution is a risk factor for respiratory infection by carrying microorganisms and affecting the body's immunity (Zhu et al. 2020). Furthermore, recent studies suggest that the cause of death of many COVID-19 patients was related to cytokine storm syndrome (Guo et al. 2020; Mehta et al. 2020). This syndrome, also known as hypercytokinemia, is an uncontrolled release of proinflammatory cytokines (Tisoncik et al. 2012). It is a severe reaction of the immune system, leading to a chain of destructive processes in the body that can end in death.

São Paulo State (SP) is the most populous and industrialized state in Brazil, with about 45 million inhabitants and 7,012 industries (IBGE 2016). Our previous studies (Zaccarelli-Marino 2012; ZaccarelliMarino et al. 2016; Zaccarelli-Marino, et al. 2019) which were conducted on a densely populated area of $\mathrm{SP}$, surrounding the Capuava Petrochemical Complex (CPC). We reported primary hypothyroidism (PH) (Zaccarelli-Marino et al. 2016; Zaccarelli-Marino et al. 2019), the increase of chronic autoimmune thyroiditis (CAT) incidence over the years (Zaccarelli-Marino 2012), and showed the evidence that iodine 
should not be considered as the responsible agent of autoimmune thyropathies in Santo André (Marino et al. 2009).

Since COVID-19 affects the pulmonary system primarily, we decided to evaluate how the virus affects individuals with pre-existing conditions on Petrochemical surroundings.

\section{Objective}

The objective of this study was to evaluate the interaction between a pre-existing condition (i.e., rhinitis, sinusitis, pharyngitis, obstructive pulmonary diseases as asthma and chronic obstructive pulmonary diseases, conjunctivitis, dermatitis, and primary hypothyroidism) in residents exposed to long-term air pollutants, and their higher risk of complications when infected with SARS-CoV-2.

\section{Methods}

\section{Atmospheric Pollutants}

Numerical simulations using the atmospheric pollutants concentrations were exploiting meteorological data for the period from 2005 to 2009, physical characteristics of the environment (topography and type of land use), and the pollutant sources (information from the physical characteristics of the sources and their emissions), correlating this data with the research done in 2003 to 2005.

For the simulations, we used the AERMOD, it is a dispersion model developed by the American Meteorological Society (AMS) and the US Environmental Protection Agency (EPA) (United States Environmental Protection Agency (US EPA) 2008) and made available for public use. We evaluated the CPC atmospheric emissions area of influence with the combination of the AERMOD dispersion model with the Weather Research Forecast (WRF) meteorological model (American Meteorological Society/Environmental Protection Agency Regulatory Model 2016) (Kumar et al. 2016).

The concentration maps for each pollutant were used to evaluate the hot spots where the population has high exposure.

The only documentation on the building downwash algorithm in AERMOD referred to as PRIME (Plume Rise Model Enhancements), new field and wind tunnel studies have shown that AERMOD can overpredict concentrations by factors of 2-8 for specific building configurations. While a wind tunnel, Equivalent Building Dimension (EBD) analysis can be conducted to approximately correct the overprediction bias, past field, and wind tunnel studies indicate that there are notable flaws in the PRIME building downwash theory.

Although AERMOD/PRIME may provide accurate and unbiased estimates (within a factor of 2) for some building configurations, a significant review and update are needed. Thus, accurate estimates can be obtained for other building configurations, where significant over predictions or underpredictions are 
common due to downwash effects (Petersen et al. 2017). Due to the impact on health, VOCs' dispersion curves were also analyzed, even though the Brazilian legislation does not regulate VOC concentrations.

\section{Study Population and Data Collection}

This study was a cohort, and we have evaluated residents living in the Capuava Petrochemical Complex (CPC) influence area in the Greater ABC region (Fig.1), from July 2003 through June 2005.

The residents were divided into two groups ( $A$ and $B$ ), based on their proximity to the industrial areas and those considered non-exposed (but do not include ambient air pollution) living in the surroundings of a different industrial area, mainly steel industries with no petroleum byproducts manufactured.

The research population was defined after the explanation about this study. Previously to data collection, free consent was signed by the father, mother, or responsible person, and authorization to this realization was obtained from the residents.

The data collected consisted of obtaining information of the residents, and a home-based questionnaire was applied in 2004 residents of both sexes aged 8-72 years old.

Group A: comprised of 1002 residents, males, and females, living in the surroundings of the CPC. This industrial area was named Region 1 and is occupied by 14 industries producing polyethylene and polypropylene from naphtha distillation and various intermediary substances used as raw materials for manufacturing other products. The area is located on the boundaries of Santo André, Mauá, and São Paulo, State of São Paulo (SP), Brazil (0.5 km, $1.0 \mathrm{~km}$, and $2.0 \mathrm{~km}$ away from CPC, respectively).

Group B comprises 1002 residents, males, and females, living in the surroundings of a different industrial area, mainly steel industries with no petroleum byproducts manufactured. The site is located on the boundaries of Santo André, São Bernardo do Campo, and São Caetano do Sul, SP, Brazil (7.5 km, 8.0 km, and $8.5 \mathrm{~km}$ away from Region 1, respectively). This industrial area was named Region 2 and was treated as the control group.

The city's population density followed the Brazilian Institute of Geography and Statistics (IBGE) (IBGE 2016). Regions 1 and 2 were divided into five cities; 334 residents were evaluated according to the distance from the CPC.

Each resident had lived in either Region, 1 or 2, for more than ten years in the same home, and the controls were matched for similar social and economic situations. The socio-economic conditions were evaluated through the questionnaire. According to the subjects themselves, the residents were selected when they had similar salaries and social habits (these residents do not have the economic needs to move far from the polluted areas). 
The residents were considered adults if they were over or equal to 18 years of age, and children and adolescents were under the age of 18 . When the residents were children or adolescents, the questions were presented to the parents or responsible persons.

The visits occurred once in each house, and to guarantee the maximal participation, we included weekends.

During the study time (2003-2005), there was no pre-selection of residents for Regions 1 and 2, and only spontaneous answers were considered. The inclusion criteria for data analysis included ages between 872 years and each resident had lived in either Region 1 or 2 for more than ten years in the same home. Residents who worked at the CPC and that lived in the Region 1 and 2 were excluded.

The survey was formulated and applied by the authors of this study.

Written questionnaires (WQ) have been widely used in epidemiologic studies. The International Study of Asthma and Allergies in Childhood (ISAAC) WQ has been previously validated by a comprehensive study (Vanna et al. 2001).

The international ISSAC was an important milestone between the epidemiological studies on the prevalence of asthma and allergic illnesses in children and adolescents. ISSAC was designed to evaluate the prevalence of asthma and allergic problems in children in different parts of the world using the standard method (written questionnaire self-applicable and or video questionnaire (Asher et al. 1995; ISAAC 1998).

The written questionnaire (WQ) self-applicate of ISAAC was the more utilized instrument due to its being easy to understand, low cost, and independent from applying a trained interviewer (Asher et al. 1995; ISAAC 1998).

The questionnaire of "The International Study of Asthma and Allergies in Childhood (ISAAC)" is a program important of an epidemiological survey established in 1991 to investigate asthma, rhinitis, and eczema in children adolescents. ISAAC for nasal symptoms was chosen for the epidemiological diagnosis of rhinitis in children and adolescents, using questions including sneeze, coryza, watery eyes, and itchy eyes (Vanna et al. 2001).

The European Community Respiratory Health Survey II (ECRHS II) was chosen for the epidemiological diagnosis of asthma and consists of questions as the prevalence of wheezing, cough, panting, the previous diagnosis, and use of medication for the treatment of asthma. It is also used to determine the incidence of allergic diseases, asthma, and reduced pulmonary function and the risk of ambient factors associated with allergic diseases and low pulmonary function (Jarvis and Burney 2002).

The questions asked on the survey were about: Identification-name (initials), age (years), sex (male, female), address and time at local residency, profession and education (adults), education (children and adolescents), and social and economic situation (adults); medical history - rhinitis was investigated 
through questions based on the same questionnaire: symptoms of a sneeze, coryza, watery eyes and itchy eyes, nasal itch, rhinorrhea, blocked nose, cough, sputum production, shortness of breath and rhinitis. All the symptoms were evaluated in children, adolescents, and adults; sinusitis with frontal headache symptoms or pain in the jaw region, posterior secretion, watery eyes, and itchy eyes and sinusitis; pharyngitis was investigated for symptoms of oropharyngeal pain, scratchiness in the throat, and difficulty to swallow and OPD, as asthma and COPD were investigated through questions based on the questionnaire. OPD was based on both person reports of symptoms like cough, sputum production and shortness of breath, chest wheeze, and asthma or COPD.

The response for rhinitis, sinusitis, pharyngitis, and OPD as asthma and COPD were only considered positive when the diagnosis and treatment were done by a doctor and took medication for these pathologies.

We selected only residents presenting with OPD as asthma and COPD and took medications to these pulmonary pathologies. Individuals taking medication that could interfere in this study, including treatments for other otorhinolaryngological and pulmonary pathologies, were excluded. Individuals with a history of smoking, other otorhinolaryngological pathologies emphysema, bronchiectasis, lung surgery, other lung diseases also were excluded.

Conjunctivitis was based on both person reports of signs and symptoms like pink or red color in the white of the eyes, watery eyes, itchiness, a gritty feeling, irritation and or burning eyes, painful eye, and photophobia.

The response to conjunctivitis was only considered positive when the residents' information about the diagnosis and treatment of sick people was made for a physician. We selected only residents presenting with conjunctivitis and who were taking medications to this pathology.

Individuals taking medication to treatments to other eye diseases, history of smoking, eye surgery, viral conjunctivitis, or bacterial, were excluded.

Dermatitis was based on both person reports of symptoms like redness, swelling, intense itching, skin lesions, such as red bumps, blisters, and pustules. The response to dermatitis was only considered positive when the residents' information about the diagnosis and treatment of sick people was made for a physician. We selected only residents presenting with dermatitis and who were taking medications to this skin pathology.

$\mathrm{PH}$ was evaluated through a questionnaire; we selected only residents presenting with $\mathrm{PH}$ and using thyroid hormone.

\section{SARS-CoV-2 database}


The number of SARS-CoV-2 cases was collected from each city of the Greater ABC Region, a traditionally industrial region of the São Paulo State, Brazil, part of the São Paulo Metropolitan Region. Five cities were chosen: Santo André, Mauá, the eastern Region of the São Paulo City, São Bernardo do Campo, and São Caetano do Sul. All information about SARS-CoV-2 cases was based on the five ABC Paulista prefectures, the São Paulo State Health Secretariat, and the Brazilian Ministry of Health (Johns Hopkins 2020; Brazil Ministry of Health 2020).

Two air pollutants categories were analyzed in this study to determine the influence of climatic factors, such as atmospheric pollution, on the rhinitis, sinusitis, pharyngitis, OPD as asthma and COPD, conjunctivitis, dermatitis, and $\mathrm{PH}$, and the higher risk of complications in the case of SARS-CoV-2.

1) Volatile organic compounds (VOCs) which have its primary source on the evaporation and leakage of the storage tanks; and

2) Criteria air pollutants, those that are controlled by the São Paulo State legislation (NO2, CO, PM10, and SO2) which are emitted by a chimney after processing. Due to the impact on health, VOCs' dispersion curves were also analyzed, even though the Brazilian legislation does not regulate VOC concentrations.

The average concentrations of each pollutant, for the Greater $A B C$ region and east of the city of São Paulo, part of the Metropolitan Region of São Paulo, state of São Paulo, Brazil, were calculated using the simulated plumes, where the questionnaires were performed: Region 1- Location: Santo André, Mauá, São Paulo. Region 2: Santo André, São Bernardo do Campo, and São Caetano do Sul.

\section{Ethical Statement}

This research was approved by the Committee of Ethics in Research of the ABC School of Medicine, SP, Brazil, and registered under number 087/2002.

\section{Statistical Analysis}

The odds of rhinitis, sinusitis, pharyngitis, obstructive pulmonary diseases as asthma and chronic obstructive pulmonary diseases, conjunctivitis, dermatitis, and primary hypothyroidism in each city were computed for each combination and compared through Wald tests with Bonferroni correction for multiple comparisons.

The association between both regions (Region 1 and Region 2) and diseases (rhinitis, sinusitis, pharyngitis, obstructive pulmonary diseases as asthma and chronic obstructive pulmonary diseases, conjunctivitis, dermatitis, and primary hypothyroidism) was compared by Chi-Square test.

The different incidence and relative complication risk of SARS-CoV-2 in association with the diseases as rhinitis, sinusitis, pharyngitis, obstructive pulmonary diseases, conjunctivitis, dermatitis, and primary 
hypothyroidism was compared by Chi-Square test.

A polynomial regression having the logarithm of the odds of diseases as response and pollutant concentration up to the third degree, along with their interactions, was fitted to the pollutant, which exhibited a consistent trend of increase in concentration with increasing distance from the Capuava Petrochemical Complex (CPC).

\section{Results}

Table 1 shows the incidence of rhinitis, sinusitis, pharyngitis, obstructive pulmonary diseases, conjunctivitis, dermatitis, and primary hypothyroidism in the two different regions, and Figure 2 displays the difference in relative complication risk of SARS-CoV-2 associated to each disease between the regions.

Table 1

Incidence of rhinitis $(\mathrm{RH})$, sinusitis (SI), pharyngitis $(\mathrm{P})$, obstructive pulmonary diseases (OPD), conjunctivitis (CO), dermatitis (DER) and primary hypothyroidism (PH) for regions 1 and 2 (same number of residents each $=1,002$ )

\begin{tabular}{|c|c|c|c|c|c|c|c|c|}
\hline Disease / Relation & RH & SI & P & OPD & CO & DER & PH & TOTAL \\
\hline Region 1 & 395 & 214 & 143 & 156 & 284 & 95 & 324 & $\mathbf{7 0 3}$ \\
\hline Region 2 & 253 & 150 & 76 & 55 & 121 & 58 & 65 & $\mathbf{2 4 4}$ \\
\hline Region 1 + 2 & 648 & 364 & 219 & 211 & 405 & 153 & 389 & $\mathbf{9 4 7}$ \\
\hline Ratio Region 1/ Region 2 & 1,56 & 1,43 & 1,88 & 2,84 & 2,35 & 1,64 & 4,98 & $\mathbf{2 , 8 8}$ \\
\hline
\end{tabular}

Figure 3 illustrates the absolute probabilities ratio of SARS-CoV-02 relative complication risk associated with rhinitis, sinusitis, pharyngitis, obstructive pulmonary diseases, conjunctivitis, and dermatitis, and primary hypothyroidism in residents who live closer to the Capuava Petrochemical Complex (CPC).

Table 2

Population density, the regions' distance from the Capuava Petrochemical Complex (CPC), and the ratio of SARS-CoV-2 deaths per 10,000 cases.

\begin{tabular}{|l|c|c|}
\hline Regions And Industrial Area Distance & Region 1 & Region 2 \\
\hline Population Density (1.000 Hab/km²) & 5,90 & 5,40 \\
\hline Industrial Area Distance (km) & 1,20 & 8,00 \\
\hline SARS-CoV-2 Deaths Ratio (Average/10,000 cases) & 9,7 & 5,5 \\
\hline
\end{tabular}

Brazilian Institute of Geography and Statistics (IBGE).Coronavirus 2 (SARS-CoV-02) data - Five prefectures of ABC Paulista, the São Paulo State Health Secretariat and the Brazilian Ministry of Health

Moreover, Figure 4 shows the absolute relation between SARS-CoV-2 deaths and the two regions' proximity to the CPC. Both tables and graphs demonstrate that the closer to Region 1 the individuals live, 
the higher the risk of death from Sars-Cov-2.

Table 3 displays the number of confirmed cases and deaths relative to coronavirus 2 (SARS-CoV-02) in Region 1 and Region 2, according to ABC Paulista prefectures, the São Paulo State Health Secretariat, and the Brazilian Ministry of Health.

Table 3

Number of confirmed cases and deaths relative to coronavirus 2 (SARS-CoV-02) in the cities of Santo André (North), Mauá and eastern São Paulo (Region 1) and Santo André (South), São Bernardo do Campo and São Caetano do Sul (Region 2).

\begin{tabular}{|l|c|c|c|c|c|c|}
\hline Region & \multicolumn{3}{|c|}{ Region 1 } & \multicolumn{3}{c|}{ Region 2 } \\
\hline Cities & Santo Andrb (North) & Maua & Sto Paulo (East) & Santo Andro (South) & saco Bernardo & Sto Caetano \\
\hline Confirmed & 2.348 & 560 & 2.181 & 2.348 & 3.482 & 1.592 \\
\hline Deaths & 105,5 & 106 & 121 & 105,5 & 274 & 69 \\
\hline Deaths Ratio/10,000 & 4,5 & 18,9 & 5,6 & 4,5 & 7,8 & 4,3 \\
\hline \hline
\end{tabular}

*Sao Rafael ( São Mateus)

Consulted on June 16, 2020, from Coronavirus 2 (SARS-CoV-02) data. Five prefectures of ABC Paulista, the State Health Secretariat of São Paulo and the Brazilian Ministry of Health

Based on the dispersion model, it was possible to estimate the average concentrations of $\mathrm{NO} 2, \mathrm{CO}$, PM10, SO2, and VOCs for Region 1 and Region 2, and they are presented in Table 4.

Table 4

Average concentrations of NO2, CO, PM10, SO2 and VOCs obtained via the simulated plume along with the distance from the CPC

\begin{tabular}{|lllllll|}
\hline Location & $\begin{array}{l}\text { Distance } \\
(\mathrm{Km})\end{array}$ & $\mathrm{NO}_{2}$ & $\mathrm{CO}$ & $\mathrm{PM}_{10}$ & $\mathrm{SO}_{2}$ & COVs \\
\cline { 3 - 7 } & $\left(\mu \mathrm{g} / \mathrm{m}^{3}\right)$ & $\left(\mu \mathrm{g} / \mathrm{m}^{3}\right)$ & $\left(\mu \mathrm{g} / \mathrm{m}^{3}\right)$ & $\left(\mu \mathrm{g} / \mathrm{m}^{3}\right)$ & $\left(\mu \mathrm{g} / \mathrm{m}^{3}\right)$ \\
\hline Region 1 & 0.5 & 13.16 & 3.95 & 0.93 & 1.36 & 477.4 \\
& 1 & 10.21 & 2.84 & 1.49 & 3.54 & 313.0 \\
\hline Region 2 & 7.5 & 2.15 & 0.69 & 0.19 & 0.34 & 10.5 \\
& 8 & 1.82 & 0.59 & 0.16 & 0.33 & 9.2 \\
\hline & 8.5 & 1.84 & 0.59 & 0.16 & 0.31 & 10.3 \\
\hline
\end{tabular}

Region 1, which is closer to the CPC, showed higher average concentrations for all pollutants and where we also found different incidences of residents with rhinitis, sinusitis, pharyngitis, obstructive pulmonary diseases, conjunctivitis, dermatitis, and primary hypothyroidism (Table 1). 


\section{Discussion}

According to our results, the average concentrations of $\mathrm{NO} 2, \mathrm{CO}, \mathrm{PM} 10, \mathrm{SO} 2$, and VOCs obtained from the simulated plumes in the cities studied are more significant when closer to the CPC (Table 4), what suggests that people living in those areas are more exposed than people leaving far away from the Petrochemical industries, what correlates with many others studies (Kalabokas et al. 2001; Ragothaman and Anderson 2017; Zaccarelli-Marino, et al. 2019).

The air pollution influence in eliciting indirect systemic effects, linked to pro-inflammation and oxidation mechanisms of the lungs, and immunological alteration processes increase the population's vulnerability to COVID-19 (Contini and Costabile 2020).

The role of chemical composition influences ecotoxicity, cytotoxicity, and genotoxicity in different ways, so that different biological outcomes are expected even in cases of similar number and mass concentrations (Lionetto et al. 2019).

Wide varieties of hazardous chemicals may originate from industrial facilities and other activities to the environment, and they are harmful to human health and the environment self (Ragothaman and Anderson 2017).

What corroborates with our findings that showed different incidences of residents with rhinitis, sinusitis, pharyngitis, OPD, conjunctivitis, dermatitis, and PH among a total of 2,004 residents from two different regions ( 1 close to the CPC and 2 further away), and a relative complication risk of SARS-CoV-2.

The absolute ratio of SARS-CoV-02 relative risk for complications associated with rhinitis, sinusitis, pharyngitis, $\mathrm{OPD}$, conjunctivitis, dermatitis, and $\mathrm{PH}$ in residents who live closer to the $\mathrm{CPC}$ is higher than those who did not have these diseases. What is coherent with studies that found prolonged exposure to air pollution has been linked to acute respiratory inflammation, asthma attack, and death from cardiorespiratory diseases in various studies (Bates et al. 1990; Schwartz et al. 1992; Schwartz et al. .1993; Dockery and Pope 1994) and the possibility of a detrimental effect of air pollution on the prognosis of patients affected by COVID-19 is plausible.

The higher concentrations of NO2, CO, PM10, SO2, and VOCs that is also above the São Paulo air quality standards, are presented inside of the CPC area (Region 1), what relates to the main signs or symptoms associated with exposure to VOCs include conjunctival irritation, nose and throat discomfort, allergic skin reaction and dyspnea (EPA 2017). Health effects of VOCs may include eye, nose, and throat irritation, which are the initial symptoms of COVID-19.

It is essential to know the atmospheric lifetime of VOCs to understand the distances they might travel in the air. A higher atmospheric lifetime indicates that the VOCs can travel a greater distance in the atmosphere, possibly impacting much farther away from the emission source (Ragothaman and Anderson 2017). 
What supports our findings, that showed the highest values of VOCs localized in the proximities of CPC, with higher than the standards for air quality in the limited area of the CPC, where were find different incidences of rhinitis, sinusitis, pharyngitis, $\mathrm{OPD}$, conjunctivitis, dermatitis, and $\mathrm{PH}$.

According to our results, 143 residents had pharyngitis in the Region closer to the CPC, affected by air pollution. In the case of COVID 19, one of the initial symptoms is a sore throat. Hence, whilst sore throat may be the symptom described by the patient, the examination might also reveal nasopharyngitis (Renner et al. 2012), and residents near the CPC should be alert to the risk of the COVID 19.

Today, Brazil is among the group of countries with the highest prevalence of allergic rhinitis in the world (Solé et al. 2006). Rhinosinusitis (RS) is characterized by inflammation of the mucosa of the nose and paranasal sinuses, constituting one of the most prevalent disorders of the upper airways.

According to our results, 395 residents had rhinitis, and 214 residents had sinusitis in the Region closer to the CPC. For its high degree of environmental contact and for having defense mechanisms more limited, the nasal cavities constitute one the organic systems more vulnerable to environmental pollutants (Shusterman 1997), increasing the vulnerability of this population to COVID-19.

Riediker et al. (Riediker et al. 2001) found the rhinoconjunctival tissue is sensitive to irritant stimuli during ongoing allergic inflammation, and those symptoms of allergic rhinoconjunctivitis might be exacerbated in areas with increased levels of air pollutants.

Conjunctivitis is most associated with 03 and NO2 exposure, although PM10 and SO2 are also correlated (Chang et al. 2012).

Our findings showed the higher values of $\mathrm{NO} 2, \mathrm{SO} 2$, and MP10, higher than the standard of São Paulo air quality, were localized in the proximities of $\mathrm{CPC}$, where we found more cases of conjunctivitis.

According to our results, 284 residents had conjunctivitis in Region 1, and dense innervations in the ocular surface are extremely sensitive to environmental chemical substances. Also, human eyes are only protected by a thin layer of the tear film, causing them to be very susceptible to the harmful effect of air pollution (Chang et al. 2012; Hong et al. 2016; Fu et al. 2017) and if these residents are affected with COVID-19, they could be at higher risk of dangerous eye complications, such as retinopathies.

Air pollution is associated with COPD's risk (Schikowski et al. 2014) and chronic laryngitis (Joo et al. 2008). It may also be a factor in transforming asthma into COPD (To et al. 2016).

In this study, 156 residents had the OPD in the Region closer to the CPC that also is affected by air pollution that causes breathlessness in most patients with severe chronic respiratory diseases, and in the case of COVID 19, one of the initial symptoms is shortness of breath.

Elevated exposure to NO2 has been associated with hypertension (Shin et al. 2020), heart and cardiovascular diseases (Mann et al. 2002; Popen et al. 2004; Gan et al. 2012) increased rate of 
hospitalization (Mann et al. 2002), COPD (Euler et al. 1988; Abbey et al. 1993), significant deficits in the growth of lung function in children (Gauderman et al. 2000; Avol et al. 2001) reduced lung function in adults or lung injury (Rubenfeld et al. 2005; Bowatte et al. 2017) and diabetes (Shin et al. 2020).

Aging has been associated with a decline in immune defenses and respiratory function, resulting in a higher predisposition to respiratory infections. Moreover, among the chronic diseases that affect the elderly population, COPD and asthma can accelerate pulmonary function decline and increase mortality risk (Bentayeb et al. 2012).

This study shows that the closer to Region 1, the higher the risk of death from SARS-CoV-2, which should be relevant to the authorities to direct attention to these populations.

Our findings showed that the higher values of NO2 localized in the proximities of CPC, and NO2 is a common tracer of air pollution/industrial activity, associated with morbidity and mortality (He et al. 2020a; He et al. 2020b).

Interdisciplinary research in air pollution and biomedical science can explain how exposure to air pollutants may affect respiratory viral infections, especially in populations already at risk for increasing the morbidity and mortality rates after infection with respiratory viruses such as COVID-19.

Recently, exposure to ambient air pollution has been implicated in the occurrence and development of autoimmune diseases (Zhao et al. 2019). Autoimmune diseases are a broad spectrum of disorders featured by the body's immune responses being directed against their tissues, resulting in prolonged inflammation and subsequent tissue damage (Zhao et al. 2019).

According to our results, 324 residents had PH in Region 1. In iodine sufficient regions, the primary cause of PH is (CAT) (Dayan 1996) and sufficiency of iodine (Marino et al. 2009; Freitas et al. 2010) and an increase of CAT incidence over the years (Zaccarelli-Marino 2012) was demonstrated in a previous study in Region 1 and could draw attention to a risk factor for the complications of SARS-COV-02.

Region 1 is unique because residents are near to petrochemical industries and environmental factors could affect the cases of rhinitis, sinusitis, pharyngitis, OPD, conjunctivitis, and $\mathrm{PH}$, and this chronic exposure could be an important contributor to the in individuals exposed to long-term air pollutants and the higher risk of complications in the case of SARS-CoV-2.

China, where the COVID-19 epidemic started, is severely affected by air pollution (He et al. 2020a; He et al. 2020b). Association between short-term exposure to air pollution and COVID-19 infection has also been described for its recent outbreak (Zhu et al. 2020).

Environmental pollution, especially air quality, has deteriorated in the past decades in China, mainly due to the country's rapid industrialization (Zhang et al. 2012). 
The spatial analysis has been conducted on a regional scale and combined with the number of death cases taken from 66 administrative regions in Italy, Spain, France, and Germany (Ogen 2020). The results showed that out of the 4,443 fatality cases, 3,487 (78\%) were in five regions located in north Italy and central Spain. Additionally, the same five regions show the highest NO2 concentrations combined with downwards airflow, which prevents an efficient dispersion of air pollution. These results indicate that the long-term exposure to this pollutant may be one of the most critical contributors to fatality caused by the COVID-19 virus in these regions and maybe across the whole world (Ogen 2020).

Since the presence of comorbidities appeared determinant for the etiology and severity of the COVID-19 symptoms (Wu et al., 2020; Chen et al. 2020; Wang et al. 2020), the role of atmospheric pollution in contributing to the high levels of SARS-CoV-2 lethality in Northern Italy has been hypothesized (Conticini et al. 2020).

In this study, we also show the higher values of NO2 localized in the proximities of CPC that could increase the risk of complications for SARS-CoV-2.

Air pollution has been termed the "silent killer" by the World Health Organization (WHO 2018) because its effects often go unnoticed or are not easily measured.

In the present time of SARS-CoV-2, air pollution may facilitate the upsurge of more severe symptoms of the disease of the eye (Chang et al. 2012; Hong et al. 2016; Fu et al. 2017), nose (Shusterman 1997), and throat (Renner et al. 2012), since these viruses may travel through the cranial nerves, producing anosmia, ageusia (lack of taste) and possibly retinopathy.

This is a pioneer study related to inflammatory diseases, such as upper and lower airways, conjunctivitis, thyroid diseases, and air pollution, and the impact of these diseases on SARS-CoV-2 pandemic infection in a population living in the surroundings of a petrochemical complex in Brazil.

We recommend that patients affected by SARS-CoV-2 should be followed up for a long time, even after medical discharge, as they may have the consequences of COVID 19, such as vascular complications and pulmonary fibrosis.

\section{Conclusions}

The population that lives close to Petrochemical industries areas with a high level of atmospheric pollution that carriers of inflammatory and autoimmune diseases have an increased risk of complications in the case of SARS-CoV-2 infection.

Given the asymptomatic characteristic of the disease in its initial development individuals and the risk of its complications, we suggest that the SARS-CoV-2 must be continuously evaluated in employees of chemical plants and residents living around industrial areas. 


\section{Declarations}

\section{Ethics approval and consent to participate}

This research was approved by the Committee of Ethics in Research of the ABC School of Medicine, SP, Brazil and registered under number 087/2002.

The objectives and methods of this study were clearly stated to all residents or to parents in the case of children. All residents agreed to participate in this study.

\section{Declaration of competing interest}

The authors declare that they have no known competing financial interests or personal relationships that could have appeared to influence the work reported in this paper.

\section{Funding}

This research received no external funding.

\section{Authors' contributions}

Maria Angela Zaccarelli-Marino participated in the design of the study, acquisition of data, interpretation of the results, draft of the manuscript and critically revised the manuscript.

Thalles Zaccarelli Balderi participated in the design of the study, acquisition of data, interpretation of the results, statistical analysis and critically revised the manuscript.

Felipe Mingorance Crepaldi participated in the design of the study, acquisition of data, interpretation of the results and literature revision.

Rudá Alessi participated in the design of the study, acquisition of data and critically revised the manuscript.

Marco Antonio Garcia Martins participated in the design of the study, interpretation of the results, critically revised the manuscript and Supervision.

All authors have read and approved the final manuscript.

\section{Acknowledgments}


The authors are grateful to the residents from Santo André, Mauá, São Paulo, São Bernardo do Campo e São Caetano do Sul, São Paulo state, Brazil, for their participation and collaboration. We also want to thank the parents and those responsible for the information and their understanding.

The authors are grateful to Professor Maria de Fatima Andrade, PhD at the University of São Paulo, Department of Atmospheric Sciences of the Institute of Astronomy, Geophysics and Atmospheric Sciences, São Paulo, SP, Brazil for her support and collaboration regarding atmospheric pollutants.

The authors are grateful to the Public Ministry of São Paulo state, Brazil, for their collaboration, support and trust.

\section{References}

1. Abbey DE, Colome SD, Mills PK, Burchette R, Beeson WL, Tian Y. Chronic disease associated with long-term concentrations of nitrogen dioxide. J Expo Anal Environ Epidemiol. 1993;3:181-202.

2. Asher MI, Keil U, Anderson HR, Beasley R, Crane J, Martinez F, Mitchell EA, Pearce N, Sibbald B, Stewart AW, Strachan D, Weiland SK. Williams H.C. International study of asthma and allergies in childhood (ISAAC): rationaleandmethods. Eur Respir J. 1995;8:48391. doi:10.1183/09031936.95.08030483.

3. Avol EL, Gauderman WJ, Tan SM, London SJ, Peters JM. Respiratory effects of relocating to areas of differing air pollution levels. Am. J Respir Crit Care Med 164:2067-2072. doi: 10.1164/ajrccm.164.11.2102005.

4. Backer JA, Klinkenberg D, Wallinga J. Incubation period of 2019 novel coronavirus (2019-nCoV) infections among travellers from Wuhan, China. January Euro Surveill Feb. 2020;6(5):20-8. doi:10.2807/1560-7917.ES.2020. 25 ):2000062.

5. Bates D, Baker-Anderson M, Sizto R.1990. Asthma attack periodicity: A study of hospital emergency visits in Vancouver. Environ. Res.1990; 51, 51-70. doi: 10.1016/s0013-9351(05)80182-3.

6. Bentayeb M, Simoni M, Baiz N, Norback D, Baldacci S, Maio S, Viegi G, Annesi-Maesano I. Geriatric Study in Europe on Health Effects of Air Quality in Nursing Homes Group Adverse respiratory effects of outdoor air pollution in the elderly. Int J Tuberc Lung Dis. 2012;16(9):1149-61. doi:10.5588/ijtld.11.0666.

7. Bi Q, Wu Y, Mei S, Ye C, Zou X, Zhang Z, Liu X, Wei L, Truelove SA, Zhang T, Gao W, Cheng C, Tang X, Wu X, Wu Y, Sun B, Huang S, Sun Y, Zhang J, Ma T, Lessler J, Feng T. Epidemiology and transmission of COVID-19 in 391 cases and 1286 of their close contacts in Shenzhen, China: a retrospective cohort study. Lancet Infect Dis. 2020;20(8):911-9. doi:10.1016/S1473-3099(20)30287-5.

8. Bowatte G, Erbas B, Lodge CJ, Knibbs LD, Gurrin LC, Marks GB, Thomas PS, Johns D, Giles GG, Hui J, Dennekamp M,. Perret JL, Abramson MJ, Walters EH, Matheson MC, Dharmage SC. Traffic-related air pollution exposure over a 5-year period is associated with increased risk of asthma and poor lung function in middle age. Eur Respir J. 2017;50(4):1602357. doi:10.1183/13993003.02357-2016. 
9. Brazil Ministry of Health. https://covid.saude.gov.br/Coronavirus resource center (World and Brazil); CVE-SES-SP (State SP); DVE / COVISA - Sivep-Gripe / ESUS VE (São Paulo city data) updated on 06/17/2020 and * SIM ProaimSMS- SP updated on 06/16/2020. Date accessed: June 17, 2020.

10. Chan JFW, Yuan S, Kok KH, To KKW, Chu H, Jin Yang J, Xing F, Liu J, Yip CCY, Poon RWS, Tsoi HW, Lo SKF, Chan KH, Poon VKM, Chan WM, Ip J, Cai JP, Cheng VCC, Chen H, Hui CKM, Yuen KY. A familial cluster of pneumonia associated with the 2019 novel coronavirus indicating person-to-person transmission: a study of a family cluster. Lancet. 2020;395(10223):514-23. doi:https://doi.org/10.1016/S0140-6736(20)30154-9tps://doi.org/10.1016/S0140-6736(20)30154-9.

11. Chang CJ, Yang HH, Chang CA, Tsai HY. Relationship between air pollution and outpatient visits for nonspecific conjunctivitis. Invest Ophthalmol Vis Sci. 2012;53(1):429-33. doi:10.1167/iovs.11-8253.

12. Chen N, Zhou M, Dong X, Chen N, Zhou M, Dong X, Qu J, Gong F, Han Y, Qiu Y, Wang J, Liu Y, Wei Y, Xia J, Yu T, Zhang X, Zhang L. Epidemiological and clinical characteristics of 99 cases of 2019 novel coronavirus pneumonia in Wuhan, China: a descriptive study. Lancet. 2020;395(10223):507-13. doi:10.1016/S0140-6736(20)30211-7.

13. Chen TM, Kuschner WG, Gokhale J, Shofer S. Outdoor air pollution: nitrogen dioxide, sulfur dioxide, and carbon monoxide health effects. Am J Med Sci. 2007;333:249-56. doi:10.1097/maj.0b013e31803b900f.

14. Conticini E, Frediani B, Caro D. Can atmospheric pollution be considered a co-factor in extremely high level of SARS-CoV-2 lethality in Northern Italy? Environ. Pollut. 2020;261:114465. doi:org/10.1016.

15. Contini D, Costabile F. Does Air Pollution Influence COVID-19 Outbreaks? Atmosphere. 2020;11(4):377. doi:org/10.3390/atmos11040377.

16. Dayan CM, Daniels GH. Chronic autoimmune thyroiditis. N Engl J Med. 1996;335:99-107. doi:10.1056/NEJM19960711335020.

17. Dockery DW, Pope CA. Acute respiratory effects of particulate air pollution. Annu Rev Public Health. 1994;15:107-32. doi.org/10.1146/annurev.pu.15.050194.000543.

18. EPA. 2017. Web Archive or the January 19, 2017. Web Snapshot. EPA - United States Environmental Protection Agency Indoor Air Quality (IAQ) Volatile Organic Compounds' Impact on Indoor Air Quality EPA Web Archive.

19. Ford ES, Murphy LB, Khavjou O, Giles WH, Holt JB, Croft JB. Total and state-specific medical and absenteeism costs of COPD among adults aged $\geq 18$ years in the United States for 2010 and projections through 2020. Chest. 2015;147(1):31-45. doi:10.1378/chest.14-0972.

20. Freitas CU, Campos RAG, Silva MAF, Panachão MRI, Moraes JC, Waissmann W, Chacra A, Maeda MYS, Rodrigues RSM, Belchor LG. Can living in the surroundings of a petrochemical complexbe a risk factor for auto-immune thyroid disease? Environ. Res. 2010;110:112-7.

21. Frontera A, Cianfanelli L, Vlachos K, Landoni G, Cremona G. Severe air pollution links to higher mortality in COVID-19 patients: the "double-hit" hypothesis. J Infect. 2020;May 21 doi:10.1016/j.jinf.2020.05.031. 
22. Fu Q, Mo Z, Lyu D, Zhang L, Qin Z, Tang Q, Yin H, Xu P, Wu L, Lou X. Air pollution and outpatient visits for conjunctivitis: A case-crossover study in Hangzhou. China Environ Pollut. 2017;231:1344-50. doi:10.1016/j.envpol.2017.08.109.

23. Gan WQ, Davies HW, Koehoorn M, Brauer M. Association of long-term exposure to community noise and traffic-related air pollution with coronary heart disease mortality. Am J Epidemiol. 2012;175:898-906. doi:10.1093/aje/kwr424.

24. Gauderman WJ, McConnell R, Gilliland F, London S, Thomas D, Avol E, Vora H, Berhane K, Rappaport EB, Lurmann F, Margolis HG, Peters J. Association between air pollution and lung function growth in southern California children. Am J Respir Crit Care Med. 2000;162:1383-90. doi:10.1164/ajrccm.162.4.9909096.

25. Godoi RH, Godoi AF, Junior SJG, Paralovo SL, Borillo GC, Barbosa CGG, Arantes MG, Charello RC, Filho NAR, Grassi MT. Healthy environment-Indoor air quality of Brazilian elementary schools nearby petrochemical industry. Sci Total Environ. 2013;463:639-46.

26. Guo YR, Cao QD, Hong ZS, Tan YY, Chen SD, Jin HJ, Tan KS, Wang DY, Yan Y. The origin, transmission and clinical therapies on coronavirus disease 2019 (COVID-19) outbreak - an update on the status. Mil Med Res. 2020;7:11. doi:10.1186/s40779-020-00240-0.

27. He L, Zhang S, Hu J, Li Z, Zheng X, Cao Y, Xu G, Yan M, Wu Y. On-road emission measurements of reactive nitrogen compounds from heavy-duty diesel trucks in China. Environ Pollut. 2020a;262:114280. doi:10.1016/j.envpol.2020.114280.

28. He MZ, Kinney PL, Li T, Chen C, Sun Q, Ban J, Wang J, Liu S, Goldsmith J, Kioumourtzoglou MA. Short- and intermediate-term exposure to NO2 and mortality: a multi-county analysis in China. Environ Pollut. 2020b;261:114165. doi:10.1016/j.envpol.2020.114165.

29. Hoek G, Krishnan RM, Beelen R, Peters A, Ostro B, Brunekreef B, Kaufman JD. Long-term air pollution exposure and cardio- respiratory mortality: a review. Environ Health. 2013;12:43.

30. Hong J, Zhong T, Li H, Xu J, Ye X, Mu Z, Lu Y, Mashaghi A, Zhou Y, Tan M. Ambient air pollution, weather changes, and outpatient visits for allergic conjunctivitis: A retrospective registry study. Sci Rep. 2016; 6.doi:10.1038/srep23858.

31. Hsu CY, Chiang HC, Shie RH. Ambient VOCs in residential areas near a large-scale petrochemical complex: Spatiotemporal variation, source apportionment and health risk. Environ Pollut. 2018;240:95-104. doi:10.1016/j.envpol.2018.04.076.

32. Huang C, Wang Y, Li X, Ren L, Zhao J, Hu Y, Zhang L, Fan G, Xu J, Gu X, Cheng Z, Ting Y, Wei XJ, Wu Y, Xie W, Yin X, Li W, Min Liu H, Xiao M, Gao Y, Guo H, Xie L, Wang J, Jiang G, Gao R, Jin Z, Wang O, Cao H. B. Clinical features of patients infected with 2019 novel coronavirus in Wuhan, China. Lancet. 2020;395:497-506. doi:10.1016/S0140-6736(20)30183-5.

33. IBGE. Brazilian Institute of Geography and Statistics. 2016. Availableonline:http://cidades.ibge.gov.br/painel/painel.php?codmun=35503 accessed May 10, 2016. 
34. IBGE. Brazilian Institute of Geography and Statistics. 2016.Available online. http://cidades.ibge.gov.br/painel/painel.php?codmun=355030. accessed June 10, 2020.

35. Jarvis D, Burney P2002. Department of Public Health Sciences. The European Community Respiratory Health Survey II Steering Committee (ECRHS II). King's College, London 2002. Eur. Respir. J. 2002;20:1071-1079. doi: 10.1183/09031936.02.00046802.

36. Johns Hopkins University http://www.conre3.org.br>portal>coronavirus. Date accessed: June 17, 2020.

37. Joo YH, Lee SS, Han KD, Park KH. Association between chronic laryngitis and particulate matter based on the Korea National Health and Nutrition Examination Survey 2008-2012. PLoS One. 2015;10(7):e0133180. doi.org/10.1371.

38. Kakodkar P, Kaka N, Baig MN. A comprehensive literature review on the clinical presentation, and management of the pandemic coronavirus disease 2019 (COVID-19) Cureus. 2020;12e7560. doi: 10.7759 /cureus.7560.

39. Kalabokas P, Hatzianestis J, Bartzis J, Papagiannakopoulos P, Hatzianestis I. Atmospheric concentrations of saturated and aromatic hydrocarbons around a Greek oil refinery. Atmos Environ. 2001;35:2545-55. doi:10.1016/S1352-2310(00)00423-4.

40. Khoder Ml. Atmospheric conversion of sulfur dioxide to particulate sulfate and nitrogen dioxide to particulate nitrate and gaseous nitric acid in an urban area. Chemosphere. 2002;49:675-84. doi:10.1016/s0045-6535(02)00391-0.

41. Kumar A, Patil RS, Dikshit AK, Islam S, Kumar R. Evaluation of control strategies for industrial air pollution sources using American Meteorological Society/Environmental Protection Agency Regulatory Model with simulated meteorology by Weather Research and Forecasting Model. J Clean Prod. 2016;116:110-7.

42. Lauer SA, Grantz KH, Bi Q, Bi Q, Jones FK, Zheng Q, Meredith HR, Azman Andrew S, Lessler J. The Incubation Period of Coronavirus Disease 2019 (COVID-19) From Publicly Reported Confirmed Cases: Estimation and Application. Ann Intern Med. 2020;172(9):577-82. ID: mdl-3215074.

43. Lewis D. Is the coronavirus airborne? Experts can't agree. Nature. 2020;580(7802):175. doi:10.1038/d41586-020-00974-w.

44. Li Q, Guan X, Wu P, Wang X, Tong YQ, Ren R, Leung KSM, Lau EHY, Wong JY, Xing X, Xiang N, Wu Y, Li C, Chen Q, Li D, Liu T, Zhao J, Liu M, Tu W, Chen C, Jin L, Yang R, Wang Q, Zhou S, Wang R, Liu H, Luo Y, Liu Y, Shao G, Li H, Tao Z, Yang Y, Deng Z, Liu B, Ma Z, Zhang Y, Shi G, Lam TTY, Wu JT, Gao GF, Cowling BJ, Yang B, Leung GM, Feng Z. Early Transmission Dynamics in Wuhan, China, of Novel Coronavirus-Infected Pneumonia. N Engl J Med. 2020;382(13):1199-207. doi:10.1056/NEJMoa2001316.

45. Lionetto MG, Guascito MR, Caricato R, Giordano M, De Bartolomeo A, Romano M, Conte M, Dinoi A, Contini D. Correlation of Oxidative Potential with Ecotoxicological and Cytotoxicological Potential of PM10 at an Urban Background Siteinltaly. Atmosphere. 2019;10(12):,733. doi:10.3390/atmos10120733. 
46. Litonjua AA, Weiss ST. Is vitamin D deficiency to blame for the asthma epidemic? J Allergy Clin Immunol. 2007;120(5):1031-5. doi:10.1016/j.jaci.2007.08.028.

47. Liu W, Tao ZW, Wang L, Yuan ML, Liu K, Zhou L, Wei S, Deng Y, Liu J, Liu HG, Yang M, Hu Y. Analysis of factors associated with disease outcomes in hospitalized patients with 2019 novel coronavirus disease. Chin Med J (Engl). 2020;133(9):1032-8. doi:10.1097/CM9.0000000000000775.

48. Liu Y, Yan S, Poh K, Liu S, lyioriobhe E, Sterling DA. Impact of air quality guidelines on COPD sufferers. Int J Chron Obstruct Pulmon Dis. 2016;11:839-72. doi:10.2147/COPD.S49378. Published 2016 Apr 21.

49. Mann JK, Tager IB, Lurmann F, Segal M, Quesenberry CP Jr, Lugg MM, Shan J, Eeden SK, Van D. Air pollution and hospital admissions for ischemic heart disease in persons with congestive heart failure or arrhythmia. Environ Health Perspect. 2002;110(12):1247-52. doi:10.1289/ehp.021101247.

50. Marino MAZ, Martins LC, Esteves RZ, Kasamatsu TS, Maciel RMB. Urinary iodine in patients with auto-immune thyroid disorders in Santo André, SP, is comparable to normal controls and has been steady for the last 10 years. Braz Arch Endocrinol Metab. 2009;53:55-63. doi:10.1590/s000427302009000100009.

51. Mehta P, McAuley DF, Brown M, Sanchez E, Tattersall RS, Manson JJ. COVID-19: consider cytokine storm syndromes and immunosuppression. Lancet. 2020;395(20):1033-4. doi:10.1016/S0140. $6736) 30628-0$.

52. Minnesota Department of Health, Minnesota Department of Health Fact Sheet April. 2010 Volatile Organic Compounds (VOCs) https://www.environix.com/wp-content/uploads/VOC-Fact-Sheet.pdf.

53. Moraes AC, Ignotti E, Netto PA, Jacobson LS, Castro H, Hacon SS. Wheezing in children and adolescents living next to a petrochemical plant in Rio Grande do Norte. Brazil J Pediatr. 2010;86(4):337-44. doi:10.2223/JPED.2020.

54. Ogen Y. Assessing nitrogen dioxide (NO2) levels as a contributing factor to coronavirus (COVID-19) fatality. Sci Total Environ. 2020;726:138605. doi:10.1016/j.scitotenv.2020.138605.

55. Omidvarborna $\mathrm{H}$, Baawain M, Al-Mamun A. Ambient air quality and exposure assessment study of the Gulf Cooperation Council countries: A critical review. Sci Total Environ. 2018;636:437-48. doi: 10.1016/j.scitotenv.2018.04.296.

56. Petersen RL, Guerra SA, Bova AS. Critical review of the building downwash algorithms in AERMOD. J Air Waste Manag Assoc. 2017;67:826-35. doi:10.1080/10962247.2017.1279088.

57. Pope CA, Burnett RT, Thurston GD, Thun MJ, Calle EE, Krewski D, Godleski J. Cardiovascular mortality and long-term exposure to particulate airpollution. Circulation. 2004;109:71-7.

Doi:10.1161/01.CIR.0000108927.80044.7F.

58. Ragothaman A, Anderson WA. Air Quality Impacts of Petroleum Refining and Petrochemical Industries. Environments. 2017;4(3):66. doi.org/10.3390/environments4030066.

59. Renner B, Mueller CA, Shephard A. Environmental and non-infectious factors in the aetiology of pharyngitis (sore throat). Inflamm Res. 2012;61(10):1041-52. doi:10.1007/s00011-012-0540-9. 
60. Ribeiro H, Assunção JV. Historical overview of air pollution in Sao Paulo metropolitan area, Brazil: influence of mobile sources and related health effects. Department of Environmental Health University of Sao Paulo, Brazil.Transactions on the Built Environment vol 52, @ 2001 WIT Press, www.witpress.com, ISSN 1743-3509.

61. Riediker M, Monn C, Koller T, Stahel WA. \& Wüthrich B. Air pollutants enhance rhinoconjunctivitis symptoms in pollen-allergic individuals. Ann Allergy Asthma Immunol. 2001;87:311-8. doi:10.1016/S1081-1206(10)62246-6.

62. Rodríguez S, Querol X, Alastuey A, Viana MM, Alarcón M, Mantilla E, Ruiz CR. Comparative PM10PM2.5 source contribution study at rural, urban and industrial sites during PM episodes in Eastern Spain. Sci Total Environ. 2004;328(1-3):95-113. doi:10.1016/S0048-9697(03)00411-X.

63. Rovira E, Cuadras A, Aguilar X, Esteban L, Borràs-Santos A, Zockd JP, Sunyer J. Asthma, respiratory symptoms and lung function in children living near a petrochemical site. Environ Res. 2014;133:156-63. doi:10.1016/j.envres.2014.05.022.

64. Rubenfeld GD, Caldwell E, Peabody E, Weaver J, Martin DP, Neff M, Stern EJ, Hudson LD. Incidence and outcomes of acute lung injury. N Engl J Med. 2005;353:1685-93. doi:10.1056/NEJMoa050333.

65. Schikowski T, Adam M, Marcon A, Cai Y, Vierkötter A, Carsin A, Jacquemin B, Kanani ZA, Beelen R, Birk M, Bridevaux PO, Brunekeefb B, Burney P, Cirach M, Cyrys J, Hoogh K, Marco R, Nazelle A, Declercq C, Forsberg B, Hardy R, Heinrich J, Hoe G, Jarvis D, Keidel D, Kuh D, Kuhlbusch T, Migliore E, Mosler G, Nieuwenhuijsen MJ, Phuleria H, Rochat T, Schindler C, Villani S, Tsai MY, Zemp E, Hansell A, Kauffmann F, Sunyer J, Probst-Hensch N. Krämer U., Künzli N. Association of ambient air pollution with the prevalence and incidence of COPD. Eur Respir J. 2014;44(3):614-26. doi:10.1183/09031936.00132213.

66. Schwartz J, Dockery DW. Particulate Air Pollution and Daily Mortality in Steubenville. Ohio Am J Epidemiology. 1992;135:12-9. doi:10.1093/oxfordjournals.aje.a116195.

67. Schwartz J, Slater D, Larson TV, Pierson WE, Koenig JQ. Particulate Air Pollution and Hospital Emergency Room Visits for Asthma in Seattle. Am RevRespir Dis. 1993;147:826-31. doi:10.1164/ajrccm/147.4.826.

68. Shin S, Bai L, Oiamo TH, Burnett RT, Weichenthal S, Jerrett M, Kwong JC, Goldberg MS, Copes R, Kopp A, Chen H. Association Between Road Traffic Noise and Incidence of Diabetes Mellitus and Hypertension in Toronto, Canada: A Population-Based Cohort Study. J Am Heart Assoc. 2020;9(6):e013021. doi:10.1161/JAHA.119.013021.

69. Shi S, Qin M, Shen B, Cai Y, Liu T, Yang F, Gong W, Liu X, Liang J, Zhao Q, Huang H, Yang B, Huang C. Association of Cardiac Injury With Mortality in Hospitalized Patients With COVID-19 in Wuhan, China. JAMA Cardiol. 2020; 25;5(7):802-810. doi: 10.1001/jamacardio.2020.0950.

70. Solé D, Wandalsen GF, Camelo-Nunes IC. Naspitz C.K. ISAAC.

71. Brazilian Group. Prevalence of symptoms of asthma, rhinitis, and atopic eczema among Brazilian children and adolescents identified by the International Study of Asthma and Allergies in Childhood (ISAAC)-Phase 3. J Pediatr. 2006;82(5):341-6. doi:10.2223/JPED.1521. 
72. Su W, Wu X, Geng X, Zhao X, Liu Q, Liu T. The short-term effects of air pollutants on influenza-like illness in Jinan, China. BMC Public Health. 2019;19(1):1319. doi:10.1186/s12889-019-7607.

73. Shusterman D. Upper respiratory tract disorders. In: LaDou J, editor. Occupational and environmental medicine. 2nd ed. Stanford: Appleton and Lange; 1997. pp. 291-304.

74. Tanyanont W, Vichit-Vadakan N. Exposure to volatile organic compounds and health risks among residents in an area affected by a petrochemical complex in Rayong Thailand. Southeast Asian $\mathrm{J}$ Trop Med Public Health. 2012;43(1):201-11.

75. Tisoncik JR, Korth MJ, Simmons CP, Farrar J, Martin TR, Katze MG. Into the eye of the cytokine storm. Microbiol Mol Biol Rev. 2012;76:16-32. doi:10.1128/MMBR.05015-11.

76. To T, Zhu J, Larsen K, Simatovic J, Feldman L, Ryckman K, Gershon A, Lougheed MD, Licskai C, Chen H, Villeneuve PJ, Crighton E, Su Y, Sadatsafavi M, Williams D, Carlsten C. Progression from asthma to chronic obstructive pulmonary disease. Is air pollution a risk factor? Am. J Respir Crit Care Med. 2016;194(4):429-38. doi:10.1164/rccm.201510-19320C.

77. United States Environmental Protection Agency (U.S. EPA). AP 42 EPA. AP42. 2008. Air Emissions Factors and Quantification, 5th ed.; Chap. 5: Petroleum Industry, v.1. Available online: ttnchie1/ap42/ch05/final/c05s01.pdf accessed December 9, 2009.

78. Vanna AT, Yamada E, Arruda LK, Naspitz CK, Solé D. International Study of Asthma and Allergies in Childhood: validation of the rhinitis symptom questionnaire and prevalence of rhinitis in schoolchildren in São Paulo, Brazil. Pediatr Allergy Immunol. 2001;12(2):95-101. doi:10.1034/j.13993038.2001.012002095.x.

79. Wang D, Hu B, Hu C, Zhu F, Liu X, Zhang J, Wang B, Xiang H, Cheng Z, Xiong Y, Zhao Y, Li Y, Wang X, Peng Z. Clinical Characteristics of 138 Hospitalized Patients With 2019 Novel Coronavirus-Infected Pneumonia in Wuhan, China. JAMA. 2020;323(11):1061-9. doi:10.1001/jama.2020.158.

80. Wang T, Du Z, Zhu F, Cao Z, An Y, Gao Y, Jiang B. Comorbidities and multi-organ injuries in the treatment of COVID-19. Lancet. 2020;395(10228):e52. doi:10.1016/S0140-6736(20)30558-4.

81. Wichmann FA, Müller A, Busi LE, Cianni N, Massolo L, Schlink U, Porta A, Sly PD. Increased asthma and respiratory symptoms in children exposed to petrochemical pollution. J Allergy Clin Immunol. 2009;123(3):632-8. doi:10.1016/j.jaci.2008.09.052.

82. WHO (World Health Organization). Geneva: 2018. Air pollution, the invisible killer. http://www.who.int/airpollution/en/. accessed December 19, 2018.

83. World Health Organization Coronavirus Disease (COVID-19). Dashboard Data last updated: 2020/6/16. Date accessed June 16, 2020.

84. WHO (World Health Organization) Director-General's remarks at the media briefing on 2019-nCoV on 11 February 2020.

85. Worldwide variation in. prevalence of symptoms of asthma, allergic rhinoconjunctivitis, and atopic eczema: ISAAC. 1998. The International Study of Asthma and Allergies in Childhood (ISAAC) Steering Committee. Lancet 351(9111):1225-32. 
86. Wu C, Chen X, Cai Y, Xia J, Zhou X, Xu S, Huang H, Zhang L, Zhou X, Du C, Zhang Y, Song J, Wang S, Chao Y, Yang Z, Xu J, Zhou X, Chen D, Xiong W, Xu L, Zhou F, Jiang J, Bai C, Zheng J, Song Y. Risk Factors Associated With Acute Respiratory Distress Syndrome and Death in Patients With Coronavirus Disease 2019 Pneumonia in Wuhan, China [published online ahead of print, 2020 Mar 13]. JAMA Intern Med. 2020;180(7):1-11. doi:10.1001/jamainternmed.2020.0994.

87. Wu F, Zhao S, Yu B, Chen YM, Wang W, Song ZG, Hu Y, Tao ZW, Tian JH, Pei YY, Yuan ML, Zhang YL, Dai FH, Liu Y, Wang QM, Zheng JJ, Xu L, Holmes EC, Zhang YZ. A new coronavirus associated with human respiratory disease in China. Nature. 2020;579(7798):265-9.

88. Zaccarelli-Marino MA. Chronic Autoimmune Thyroiditis in Industrial Areas in Brazil: A 15 Year Survey. J Clin Immunol. 2012;32(5):1012-8.

89. doi: 10.1007/s10875-012-9703-2.

90. Zaccarelli-Marino MA, Alessi R, Balderi TZ, Martins MAG. Association between the Occurrence of Primary Hypothyroidism and the Exposure of the Population Near to Industrial Pollutants in São Paulo State, Brazil. Int J Environ Res Public Health. 2019;16(18):3464. doi:10.3390/ijerph16183464.

91. Zaccarelli-Marino MA, André CDS, Singer JM. Overt Primary Hypothyroidism in an Industrial Area in São Paulo, Brazil: The Impact of Public Disclosure. Int J Environ Res Public Health. 2016;13(11):,1161. doi:10.3390/ijerph13111161.

92. Zhang J, Mauzerall DL, Zhu T, Liang S, Ezzati M, Remais JV. Environmental health in China: progress towards clean air and safe water. Lancet. 2010;375(9720):1110-9. doi:10.1016/S01406736(10)60062-1.

93. Zhang XY, Wang YQ, Niu T, Zhang XC, Gong SL, Zhang YM, Sun JY. Atmospheric aerosol compositions in China: spatial/temporal variability, chemical signature, regional haze distribution and comparisons with global aerosols. Atmos Chem Phys. 2012;12(2):779-99. doi:10.5194/acp-126273-2012.

94. Zhao CN, Xu Z, Wu GC, Mao YM, Liu LN, Qian-Wu DYL, Tao SS, Zhang Q, Sam NB, Fan YG, Zou YF, Ye DQ, Pan HF. Emerging Role of Air Pollution in Autoimmune Diseases. Autoimmunity Rev. 2019;18(6):607-14. doi:10.1016/j.autrev.2018.12.010.

95. Zhu Y, Xie J, Huang F, Cao L. Association between short-term exposure to air pollution and COVID-19 infection: evidence from China. Sci Total Environ. 2020;727:138704. doi:10.1016/j.scitotenv.2020.138704.

\section{Figures}




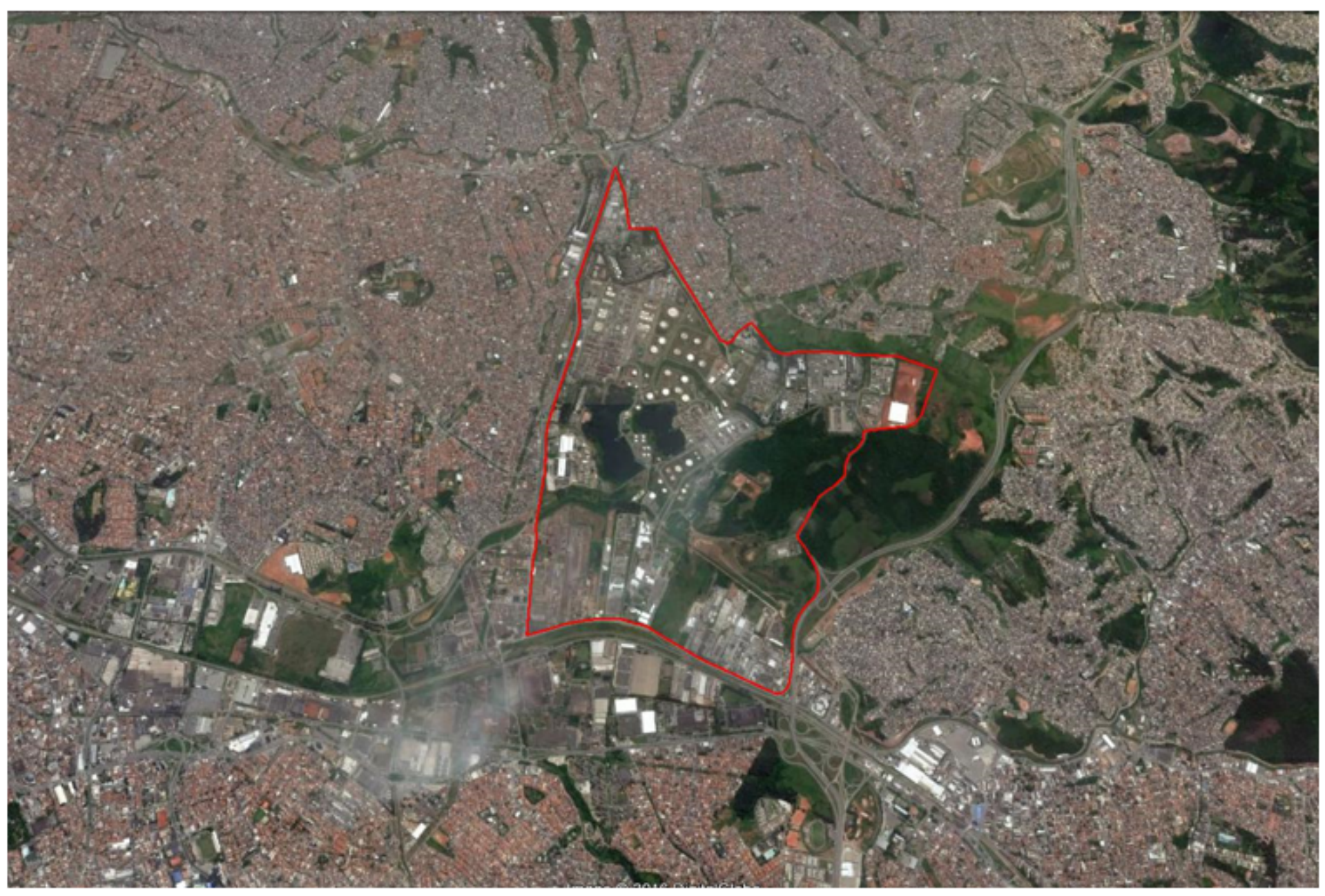

\section{Figure 1}

Satellite map of the region where the Capuava Petrochemical Complex (CPC) (surrounded by red) is located in the city of Mauá-SP and bordering Santo André-SP 


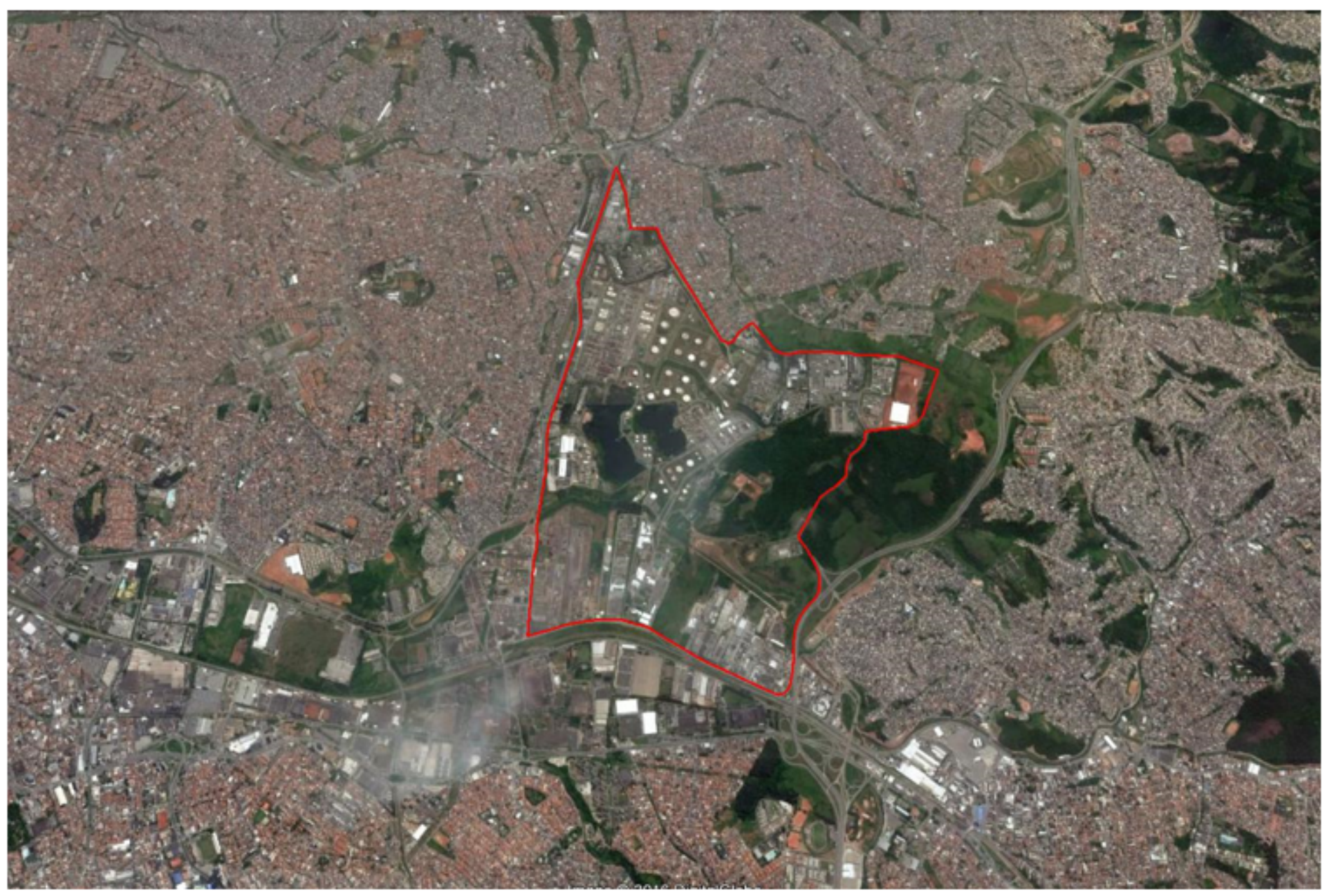

\section{Figure 1}

Satellite map of the region where the Capuava Petrochemical Complex (CPC) (surrounded by red) is located in the city of Mauá-SP and bordering Santo André-SP

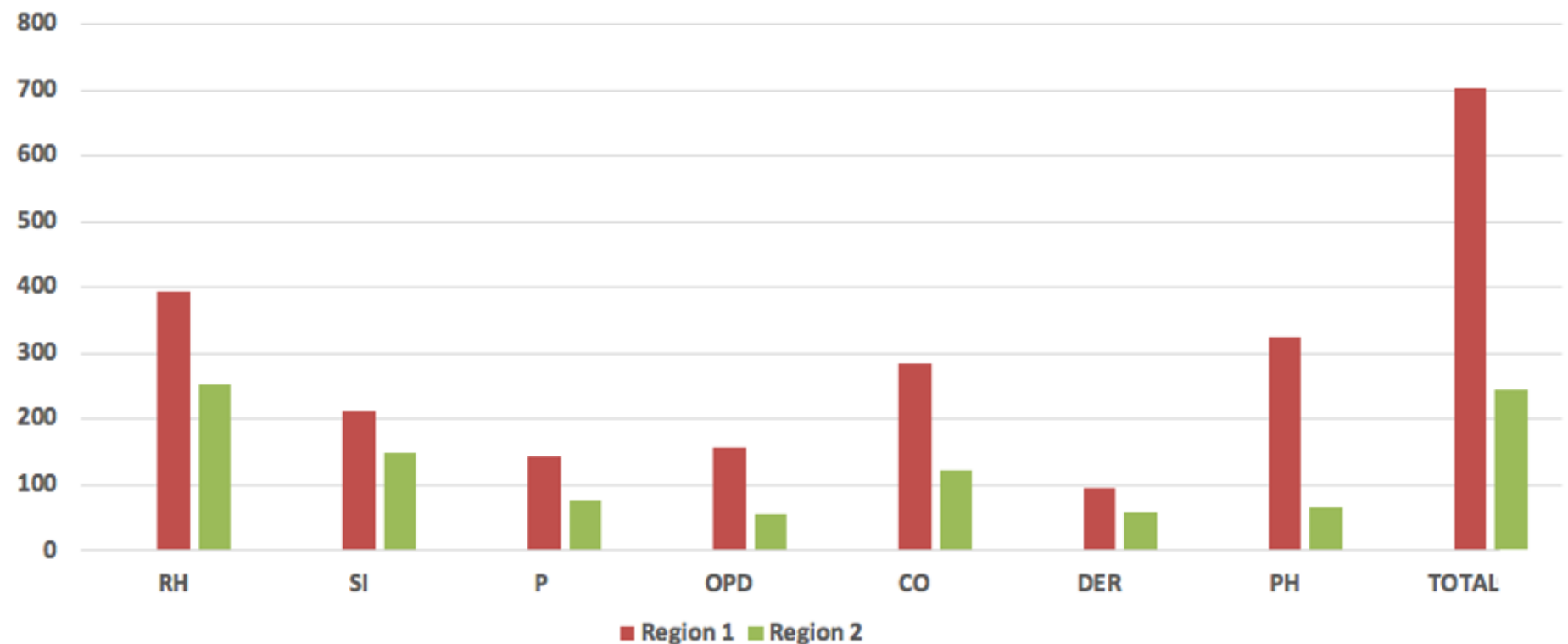


Figure 2

Difference in the relative complication risk of SARS-CoV-2 associated with diseases: rhinitis (RH), sinusitis (SI), pharyngitis (P), obstructive pulmonary diseases (OPD), conjunctivitis (CO), dermatitis (DER) and primary hypothyroidism $(\mathrm{PH})$

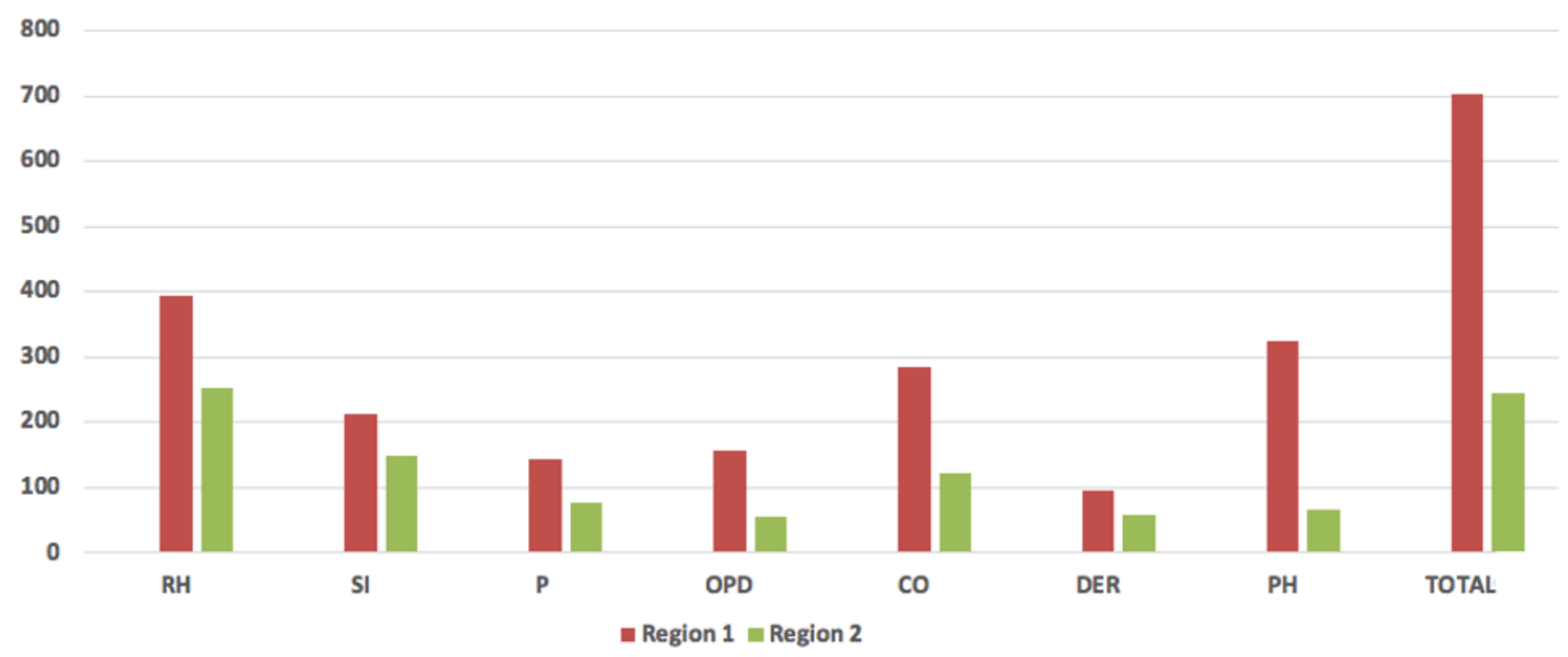

Figure 2

Difference in the relative complication risk of SARS-CoV-2 associated with diseases: rhinitis (RH), sinusitis (SI), pharyngitis (P), obstructive pulmonary diseases (OPD), conjunctivitis (CO), dermatitis (DER) and primary hypothyroidism $(\mathrm{PH})$

\section{6}

5

4

3

2

1

0

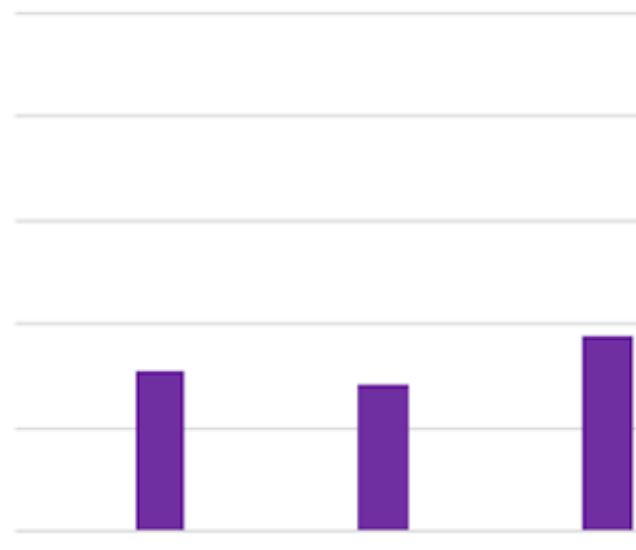

RH

SI

P

OPD

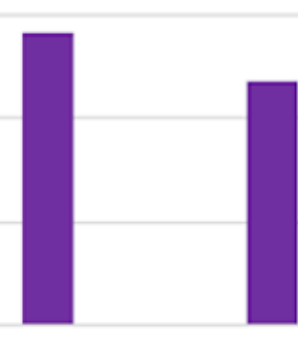

CO

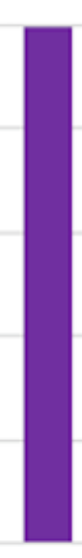

PH

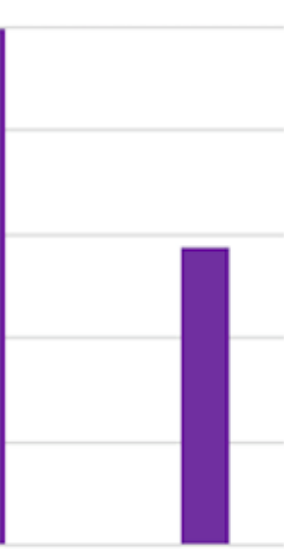

DER

TOTAL

Figure 3 
Absolute odds ratio of SARS-CoV-02 relative complication risk in association with each disease - rhinitis $(\mathrm{RH})$, sinusitis $(\mathrm{SI})$, pharyngitis $(\mathrm{P})$, obstructive pulmonary diseases (OPD), conjunctivitis (CO), dermatitis (DER) and primary hypothyroidism (PH) - in CPC

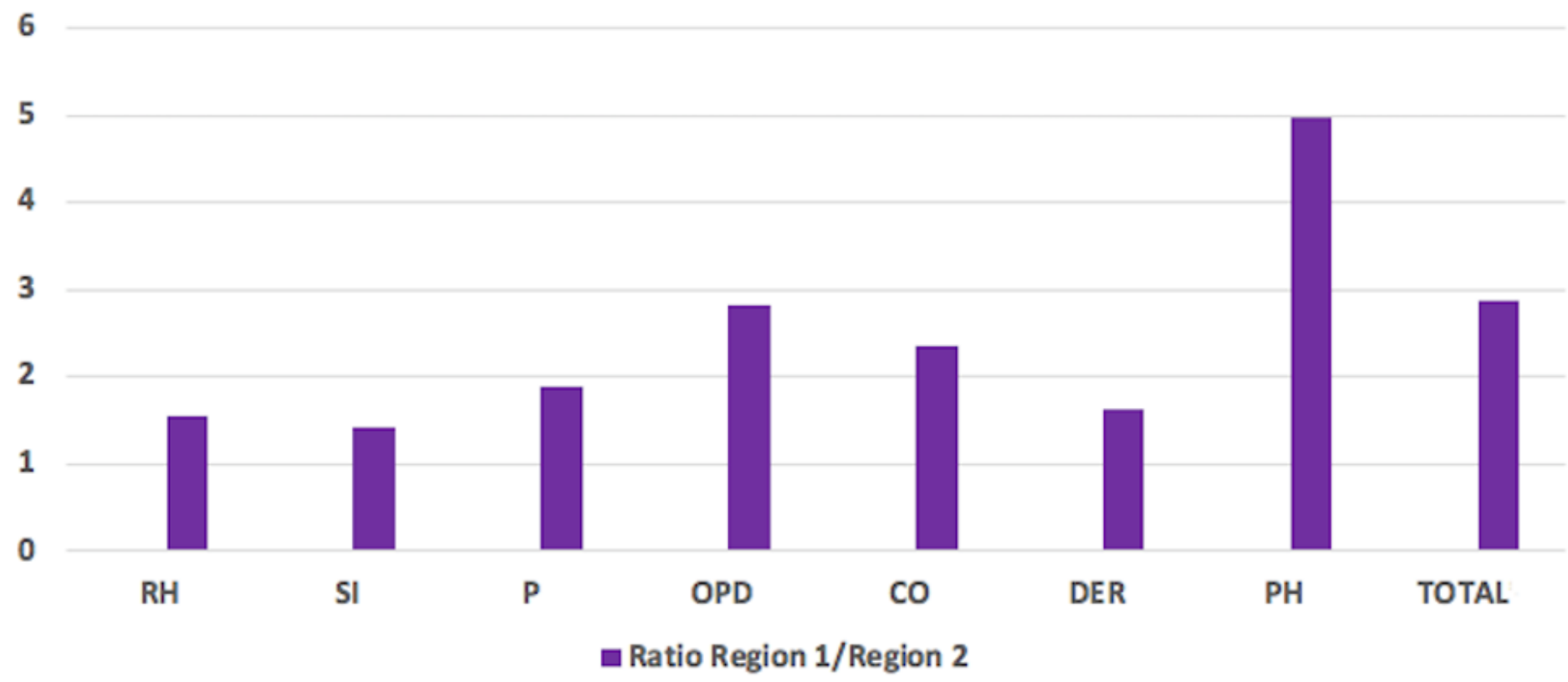

\section{Figure 3}

Absolute odds ratio of SARS-CoV-02 relative complication risk in association with each disease - rhinitis $(\mathrm{RH})$, sinusitis $(\mathrm{SI})$, pharyngitis $(\mathrm{P})$, obstructive pulmonary diseases (OPD), conjunctivitis (CO), dermatitis (DER) and primary hypothyroidism (PH) - in CPC

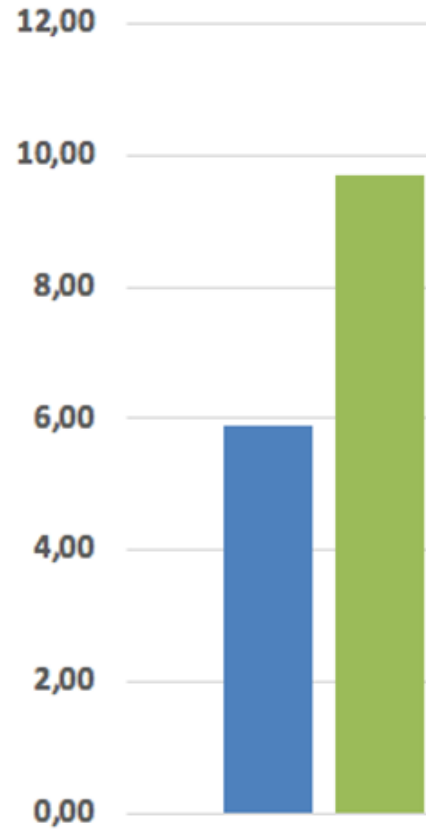

Region 1
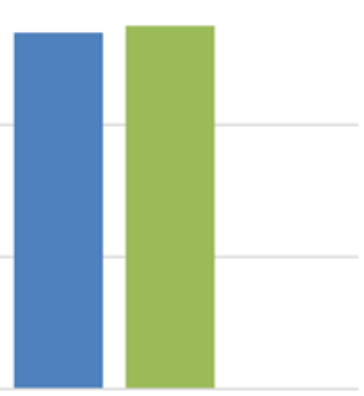

Region 2

\# Population Density (1.000 Hab/km2) $\quad$ - Sars-Cov-2 Deaths Ratio (Average/10,000 cases) 


\section{Figure 4}

Absolute relation between SARS-CoV-2 deaths and the two regions' proximity to the CPC. The regions have a similar population density.

$$
12,00
$$

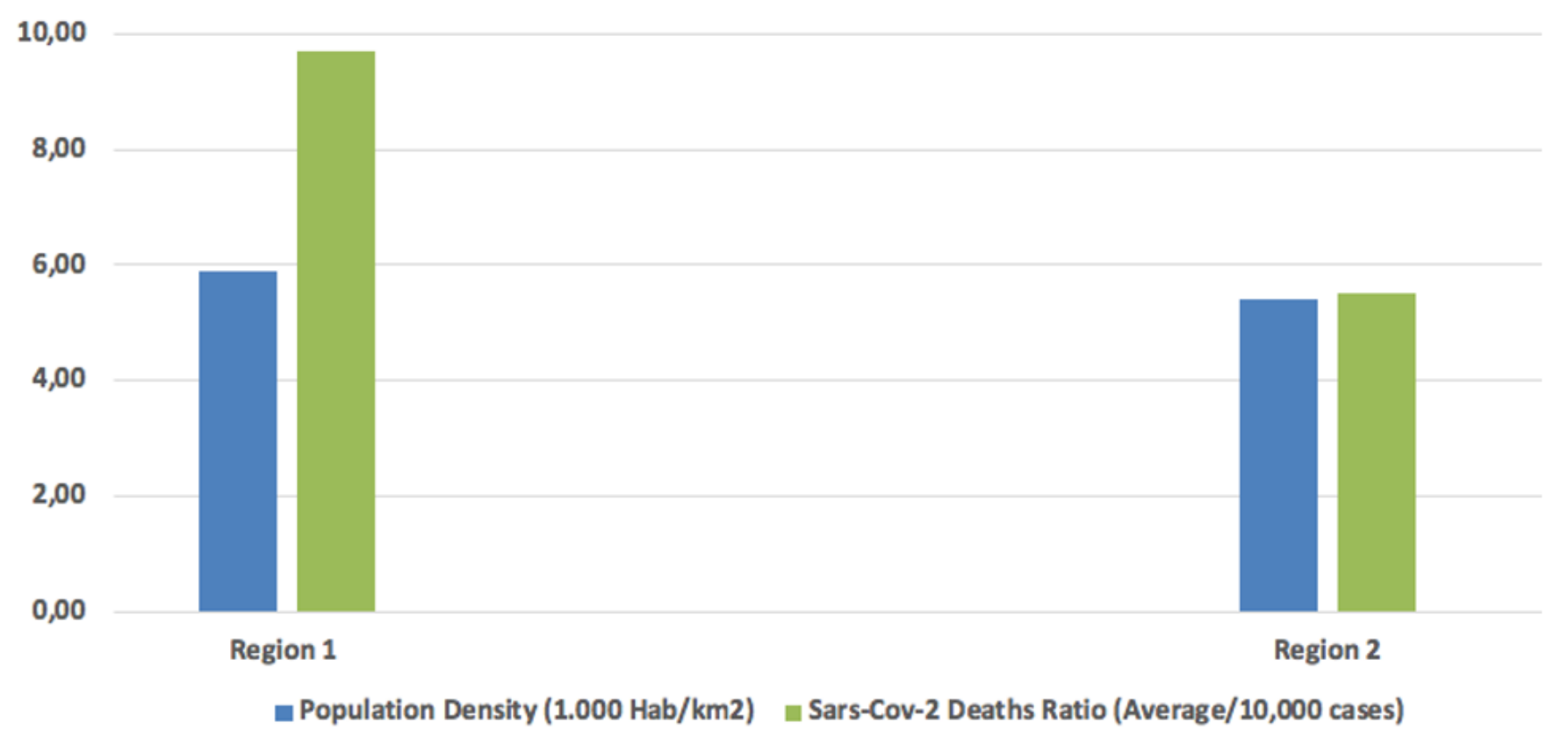

\section{Figure 4}

Absolute relation between SARS-CoV-2 deaths and the two regions' proximity to the CPC. The regions have a similar population density. 